\title{
N-Acetylglucosamine Sensing and Metabolic Engineering for Attenuating Human and Plant Pathogens
}

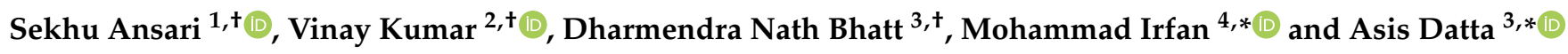 \\ 1 Division of Pathology, Cincinnati Children's Hospital Medical Center, Cincinnati, OH 45229, USA; \\ shekhuansar@gmail.com \\ 2 Department of Physiology and Cell Biology, Department of Internal Medicine, The Ohio State University \\ Wexner Medical Center, Columbus, OH 43210, USA; vinayktyagi07@gmail.com \\ 3 National Institute of Plant Genome Research, Aruna Asaf Ali Road, New JNU Campus, \\ New Delhi 110067, India; mashbh101@gmail.com \\ 4 Plant Biology Section, School of Integrative Plant Sciences, Cornell University, Ithaca, \\ New York, NY 14453, USA \\ * Correspondence: mi239@cornell.edu (M.I.); asis_datta@rediffmail.com (A.D.) \\ + Authors contributed equally to the review and share the first authorship.
}

check for updates

Citation: Ansari, S.; Kumar, V.; Bhatt, D.N.; Irfan, M.; Datta, A. N-Acetylglucosamine Sensing and Metabolic Engineering for Attenuating Human and Plant

Pathogens. Bioengineering 2022, 9, 64 . https://doi.org/10.3390/

bioengineering 9020064

Academic Editors: Pumtiwitt

C. McCarthy and James Wachira

Received: 31 December 2021

Accepted: 3 February 2022

Published: 5 February 2022

Publisher's Note: MDPI stays neutral with regard to jurisdictional claims in published maps and institutional affiliations.

Copyright: (c) 2022 by the authors. Licensee MDPI, Basel, Switzerland. This article is an open access article distributed under the terms and conditions of the Creative Commons Attribution (CC BY) license (https:/ / creativecommons.org/licenses/by/ $4.0 /)$.

\begin{abstract}
During evolution, both human and plant pathogens have evolved to utilize a diverse range of carbon sources. N-acetylglucosamine (GlcNAc), an amino sugar, is one of the major carbon sources utilized by several human and phytopathogens. GlcNAc regulates the expression of many virulence genes of pathogens. In fact, GlcNAc catabolism is also involved in the regulation of virulence and pathogenesis of various human pathogens, including Candida albicans, Vibrio cholerae, Leishmania donovani, Mycobacterium, and phytopathogens such as Magnaporthe oryzae. Moreover, GlcNAc is also a well-known structural component of many bacterial and fungal pathogen cell walls, suggesting its possible role in cell signaling. Over the last few decades, many studies have been performed to study GlcNAc sensing, signaling, and metabolism to better understand the GlcNAc roles in pathogenesis in order to identify new drug targets. In this review, we provide recent insights into GlcNAc-mediated cell signaling and pathogenesis. Further, we describe how the GlcNAc metabolic pathway can be targeted to reduce the pathogens' virulence in order to control the disease prevalence and crop productivity.
\end{abstract}

Keywords: N-Acetylglucosamine; pathogens; virulence; colonization; NAG1; DAC1; HXK1; NGT1; chitin; plant immunity

\section{Introduction}

Pathogens have developed numerous strategies for successful host colonization, which depends upon their ability to cope with a poor nutritional environment for the pathogens and stressful conditions inside the host. The pathogenesis mechanism involves multifarious parallel metabolic pathways, complex gene regulatory network systems, and stress adaptive mechanisms to survive inside the host [1]. During infection, many human pathogens target phagocytic cells, especially macrophages [2]. In the defense mechanism against pathogens, macrophages apply several stress mechanisms like oxidative and nitrosative stress to kill the pathogens [3]. Pathogens evade this host defense mechanism to reach the parasitophorous vacuole. To restrict the growth of phagocytosed pathogens, phagocytic cells maintain a low level of glucose inside their parasitophorous vacuole (PV) [2]. PV has a nutritionally poor and stressful environment. One of the adaptative strategies that evolved in pathogens is their capability to utilize a diverse range of carbon sources for their survival under hostile environments [1]. Under these circumstances, the parasites living inside the PV depend heavily on the amino sugars present inside the PV. Amino sugars (N-acetylglucosamine and Glucosamine) are a major class of non-conventional sugars 
consumed by pathogens in the absence of conventional carbon sources. Therefore, the utilization of N-acetylglucosamine (GlcNAc) as a carbon source under hostile conditions is an important adaptive mechanism found in many human pathogens [4-7]. Most of the cells could not synthesize non-phosphorylated GlcNAc. Therefore, GlcNAc is synthesized de novo either, in the form of GlcNAc-6-P or GlcNAc-1-P, inside the cell. Hence, the free form of GlcNAc is never expected inside the cell unless it is taken up from the outside source. Prokaryotes synthesize GlcNAc-1-P, while eukaryotic cells synthesize GlcNAc6-P [8]. Accordingly, depending upon the phosphorylation or non-phosphorylation of GlcNAc, cells distinguish between the endogenous and exogenous GlcNAc.

In plants, pathogenic fungi, which severely affect crop production, change the host metabolism upon fungal invasion [9-14]. Fungal pathogens either kill the host cells to get nutrients by consuming the dead tissues in a necrotrophic or establish a long-term feeding association with the host instead of killing the host cells in a biotrophic interaction fashion [15-18]. During pathogenesis, the host cell death or hypersensitive response is caused by reactive oxygen species (ROS) and used by the host as a defense tool against biotrophic pathogens. The hypersensitive response-mediated cell death or resistance against biotrophs can result in increased susceptibility against necrotrophic pathogens and vice versa $[19,20]$. Thus, hosts employ different defense strategies depending on the nature of pathogens [21-23]. The fungal cell wall contains chitin, a GlcNAc polymer, and is synthesized by chitin synthases using UDP-GlcNAc, generated from different sugars. Chitin is broken down into its monomers during fungal cell wall remodeling [8]. Therefore, GlcNAc is an important component during chitin metabolism, cell wall remodeling, and host colonization by fungal pathogens.

In this review, we provide recent insights into GlcNAc sensing and signaling mechanisms in different human and plant pathogens. We discuss how the GlcNAc metabolic pathway has been targeted to reduce the virulence of these severe pathogens using different molecular genetics, biotechnology, and genome engineering tools. Moreover, the prospects of GlcNAc and its metabolic pathway genes as tools for drug discovery and plant immunity have also been discussed.

\section{GlcNAc: A Ubiquitous Amino Sugar and Signaling Molecule}

The ubiquitous presence of the GlcNAc makes it among the most abundant sugars on Earth. GlcNAc is present in almost all life forms present on Earth, such as archaebacteria, mycoplasma, bacteria, fungi, plants, and animals [8]. GlcNAc has a diverse role in different biological processes, as shown in Figure 1. GlcNAc is particularly known for its structural role in distinct cell types across living organisms. In bacteria, GlcNAc provides structural support by forming the backbone of the cell wall in the form of peptidoglycan $[8,24]$. In fungi, GlcNAc provides structural support in the form of chitin [8]. In multicellular organisms, the intercellular space is packed with an organized meshwork of extracellular matrix. It provides structural and biochemical support to the cells. The extracellular matrix contains a wide range of sugar polymers like glycosaminoglycans, heparin sulfate, and keratin sulfate [25]; most have GlcNAc as a monomer. Among these macromolecules, glycosaminoglycans form a major part of the extracellular matrix in humans. Besides the extracellular matrix, GlcNAc is also abundantly present at mucosal sites like the gastrointestinal tract and vaginal and oral thrush [26]. These mucosal sites are often the site of entry inside the body for several pathogens. Several pathogens, including C. albicans, colonize the mucosal membranes of the GI tract, oral cavity, and vaginal thrush (Figure 2; Table 1) $[27,28]$. GlcNAc is also present in plants, albeit in trace amounts. However, it is mainly found in the form of glycosylated proteins [29]. In plants, many studies have shown that different free N-glycans in the common core (Man3Glc NAc2) regulate various biological processes [30-34]. Plant membrane sphingolipids, e.g., glucosamine inositol phosphorylceramide, also contain GlcNAc and are involved in cell-cell adhesion [35]. 


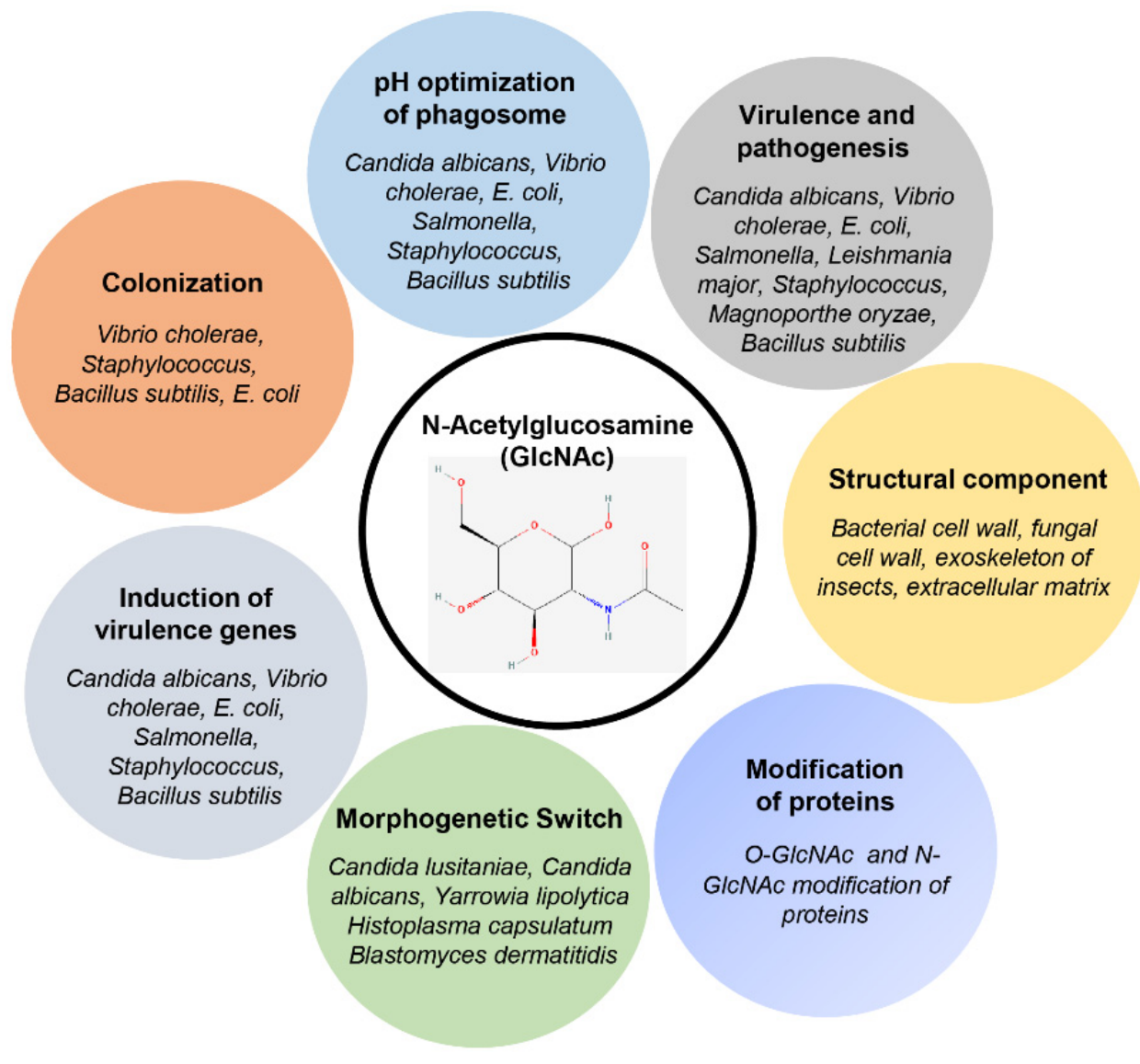

Figure 1. Diverse roles of GlcNAc. The GlcNAc plays a key role in pathogenesis and provides a survival advantage to the pathogens in the host. The chemical structure of GlcNAc (PubChem CID 439174) retrieved on 19 January 2022 from https:/ / pubchem.ncbi.nlm.nih.gov/compound/N-AcetylD-Glucosamine.

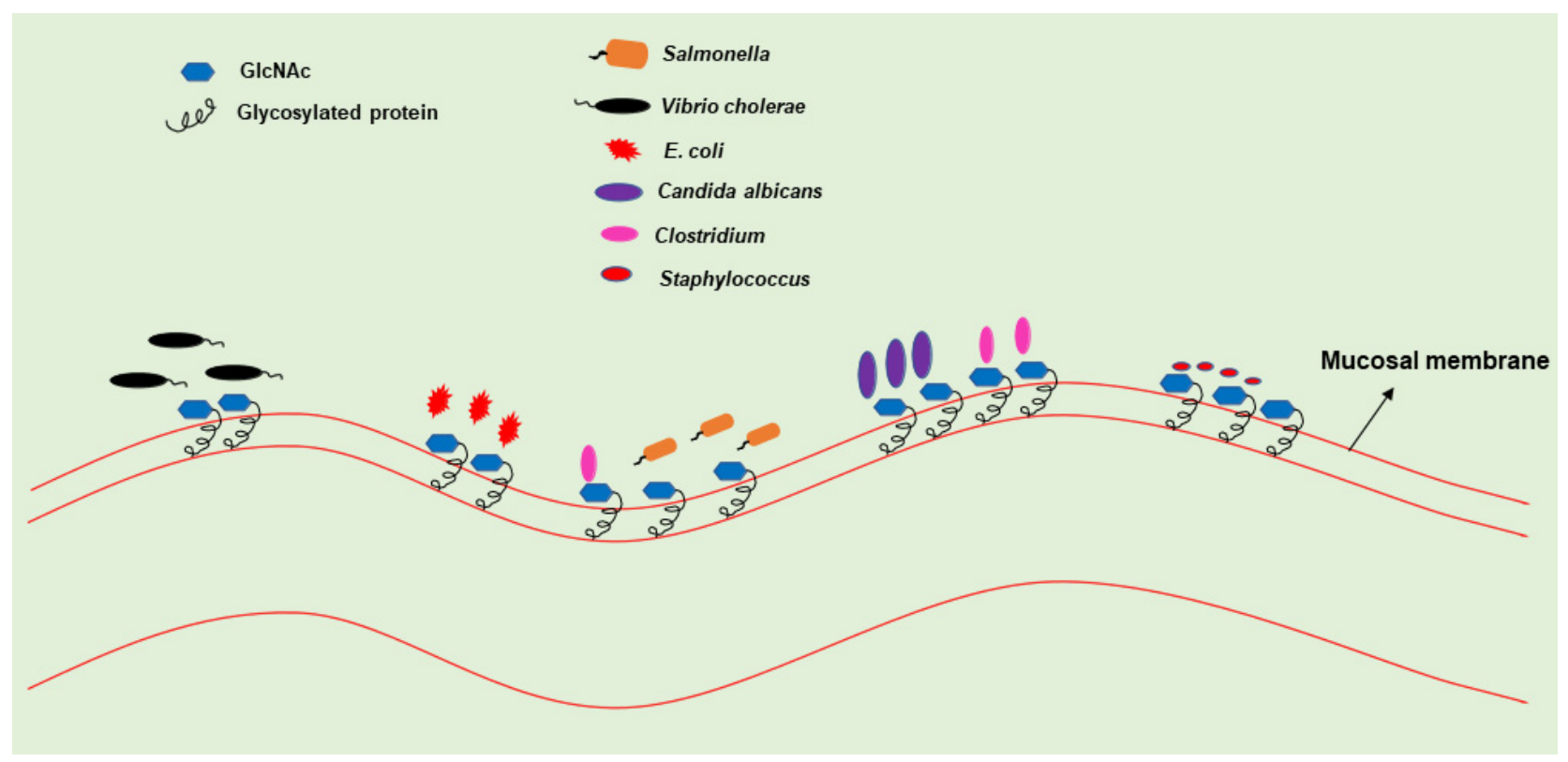

Figure 2. Pathogen infection at mucosal membrane: Mucous membrane is rich in glycosylated proteins. Several pathogens such as Candida albicans, E. coli, Salmonella spp., Vibrio cholerae, etc., exploit GlcNAc released from glycoproteins at the mucosal membrane. 
Table 1. Microorganisms and associated host cell surface protein and pathogen infection at mucosal membrane. Mucous membrane is rich in glycosylated proteins and several pathogens, such as Candida albicans, Escherichia coli, Salmonella, Vibrio cholerae, etc., exploit glycoproteins at the mucosal membrane.

\begin{tabular}{ccccc}
\hline Microbes & Cell Surface Protein & Organ/Tissue & Disease & References \\
\hline Helicobacter pylori & Mucin 5AC (MUC5AC) & Gastric mucosa & Peptic ulcers \\
Nibrio cholerae & $\begin{array}{c}\text { N-acetylneuraminic acid } \\
\text { (Neu5Ac) and }\end{array}$ & Small intestine & Cholera \\
Salmonella enterica & N-acetylglucosamine (GlcNAc) & [36] & Typhoid \\
Leishmania species & Neuraminidase 1 & Intestinal epithelial cells & Skin, spleen, and liver & Leishmaniasis \\
Toxoplasma gondii & (NEU 1) & Spleen, lung, etc. & Toxoplasmosis \\
Enterotoxigenic & MUC2 & Large intestine & Noninflammatory \\
Escherichia coli & Msb2 & Douth, throat, gut, & Diarrheas \\
Candida albicans & and vagina & Candidiasis & [39] \\
Akkermansia muciniphila & Gastrointestinal mucin & Gastrointestinal tract & [42] \\
Clostridioides difficile & O-glycan mucin & Gastrointestinal tract & Diarrhea \\
Staphylococcus aureus & Nasal mucin & Brain, heart, and lung & Pneumonia and Meningitis \\
\hline
\end{tabular}

During infection, pathogens secrete a huge amount of hyaluronidases to release the GlcNAc present in the mucosal membrane and ECM [7]. This GlcNAc is used as a carbon source by pathogens during the initial penetration of the human body. Hyaluronidase secretion also stimulates the recruitment of the phagocytic cells to the site of infection. Pathogens are then taken up by macrophages. Inside the macrophages, these pathogens end up being inside the phagolysosomal compartment. These compartments are acidic and rich in hydrolytic enzymes [50]. These phagolysosomal compartments regularly receive waste macromolecules of the cells like glycoproteins, proteoglycans, and glycolipids [1,2,51]. These macromolecules are then degraded by the hydrolases to release the GlcNAc. Since macrophages regularly maintain low glucose levels, pathogens depend heavily upon the GlcNAc released from macromolecules. Therefore, the ubiquitous presence of GlcNAc from the cell surface to the extracellular matrix to the inside of the cell makes it one of the most important sugars for the pathogen. Moreover, numerous proteins in the cytoplasm and nucleus are also regulated by GlcNAc, probably at serine and threonine residues (O-GlcNAc) by the O-GlcNAc transferase [52]. GlcNAc is also reported as an inducer of Candida albicans morphological plasticity (yeast to hyphae transition), a pathogenic trait as the hyphal form has significant roles in the infection process [53]. To understand this, various proteomics approaches have been employed, and many GlcNAc-regulated protein and phosphoproteins involved in morphological transition were identified [54,55].

There is growing evidence that GlcNAc acts as an intracellular signaling molecule in signaling pathways that impact the virulence and survival of the pathogens in hosts such as Candida albicans [24,56]. The first report of GlcNAc as a signaling molecule was reported in the human fungal pathogen C. albicans. GlcNAc induces the switching of the budding yeast form to the filamentous hyphal form in C. albicans [53]. This switching in morphology is c-AMP-mediated. Later, this role of GlcNAc-induced morphogenesis into the filamentous form was discovered in several other fungal pathogens. Hyphal forms of fungus show invasive growth in hosts. GlcNAc also induces several genes (aspartyl proteases, phospholipases, adhesins, etc.) involved in the virulence and biofilm formation in C. albicans [8]. Besides providing the energy, GlcNAc catabolism plays a vital role in raising the $\mathrm{pH}$ of the acidic phagolysosome, thereby providing the ambient $\mathrm{pH}$ for its survival [57]. GlcNAc also induces the galactose metabolic pathway in C. albicans, which is very unusual as both catabolic pathways do not overlap [58].

In bacterial pathogens, GlcNAc regulates several virulence factors. In E. coli, GlcNAc downregulates the expression of the fimbriae and curli fibers, which are important virulence determinant factors [8]. GlcNAc also regulates the production of secondary metabolites 
in bacteria. Production of antibiotics by the soil bacteria and phenazine (antimicrobial compound) by P. aeruginosa is induced by the GlcNAc-mediated signaling [8]. In pathogenic bacteria, Listeria monocytogenes flagellar motility is modulated by the O-GlcNAcylation of the flagellar protein [59]. In the mammalian system, GlcNAc is a major constituent of the ECM. GlcNAc is released during the remodeling of ECM or the parasitic infection through hyaluronidases; a significant amount of GlcNAc is released, which acts as a signaling molecule for both mammalian cells and parasites [7]. Several mammalian cell surface proteins regulate the cell signaling pathways by altering the pattern of $\mathrm{N}$-glycosylation. GlcNAc has also been found to influence the mammalian immune cells. GlcNAc inhibits the T-cell response. The Th1 and Th17 cell-response against the fungal defense is inhibited by GlcNAc [60]. Not much is known about GlcNAc inhibition of the T-cell response.

Depending upon the metabolic requirements of the cells, GlcNAc can either enter the catabolic pathway for energy generation, or it can enter the anabolic pathway for the biosynthesis of other cellular metabolites. Amino sugars are required for the biosynthesis of a wide range of surface glycoconjugates and N-glycosyl modification of proteins. This role of amino sugars is well established from lower prokaryotes to higher eukaryotes [8]. GlcNAc can be converted to UDP-GlcNAc, and this UDP-GlcNAc is used by the cell for the biosynthesis of several glycoconjugates like glycosylphosphatidylinositol (GPI), dolichol-linked oligosaccharides (DLO), gp63, PSA2, LPG. UDP-GlcNAc is also essential for the glycosylation of proteins. The biosynthesis of UDP-GlcNAc is also crucial for the survival of several pathogens. UDP-GlcNAc biosynthesis is critical for the survival of Trypomastigote-the bloodstream form of T. brucei [61]. UDP-GlcNAc synthesis is important for the intracellular survival of Mycobacteria tuberculosis [62]. In many bacterial and fungal pathogens, UDP-GlcNAc acts as a GlcNAc donor for the cell wall synthesis and glycosylation of proteins [8].

\section{Universality of GlcNAc Catabolic Pathway and Genes in Human and Plant Pathogens}

Various studies demonstrate that the GlcNAc catabolic pathway is evolutionary conserved in human and plant pathogens (Figure 3). The genes of the GlcNAc catabolic pathway have been identified in human bacterial pathogens such as Mycobacterium, Vibrio cholerae, yeast ascomycetes, filamentous ascomycetes, basidiomycetes and zygomycetes fungi, and protozoan parasites $[1,4,52,63]$. Similarly, the genes involved in GlcNAc utilization are identified in the genomes of several phytopathogenic fungi, including $M$. grisea, Gibberella zeae, Ustilago maydis, Sclerotinia sclerotiorum,, Botryotinia fuckeliana, Pyrenophora tritici-repentis, Cochliobolus heterostrophus, Mycosphaerella fijiensis, Nectria haematococca, and Aspergillus niger [64,65]. This unique nature of the GlcNAc catabolic pathway suggests an important role of the gene cluster in pathogenesis. In pathogens, including $V$. cholera, C. albicans, and M. oryzae, the GlcNAc catabolic pathway genes are present as a cluster in an operon [52]. In C. albicans, GlcNAc catabolic pathway genes are clustered together on chromosome 6 [52]. However, in protozoan parasites, like L. donovani, these genes are present on separate chromosomes [1,2].

Free GlcNAc is released by the glycosidases, such as is taken up the bacterial cells through their phosphotransferase system (PTS), while eukaryotes have specific transporters for the GlcNAc [8,66]. For pathogens such as C. albicans, M. oryzae has Ngt1 for GlcNAc import (Figure 3). Inside the eukaryotic cells, three enzymes, namely: hexokinase (HXK), N-acetyl glucosamine-6-phosphate deacetylase (DAC), and glucosamine-6phosphate deaminase (NAG), function in a sequential manner in the catabolism of GlcNAc (Figure 3) $[8,52,65]$. These three enzymes are highly conserved in pathogens. GlcNAc is phosphorylated by HXK to form N-acetylglucosamine-6-phosphate (GlcNAc-6-P) [7,8,52]. GlcNAc-6-P is then deacetylated by DAC to form the glucosamine-6-phosphate (GlcN6-P) $[52,65]$. Further, GlcN-6-P is deaminated and isomerized by NAG to form fructose 6-phosphate [52,65]. Fructose-6-phosphate is a common metabolic intermediate having multiple fates, which can be used for generating the energy requirement of the cell $[8,52,65]$. 
In most pathogens, GlcNAc catabolism closely follows the glycolytic pathway. Therefore, the GlcNAc catabolism takes place in the cytoplasm of the cell. However, in pathogens, like Leishmania, Trypanosoma glycolytic enzymes are localized in glycosomes. Thus, in these pathogens, GlcNAc catabolism takes place in glycosomes [1,2].

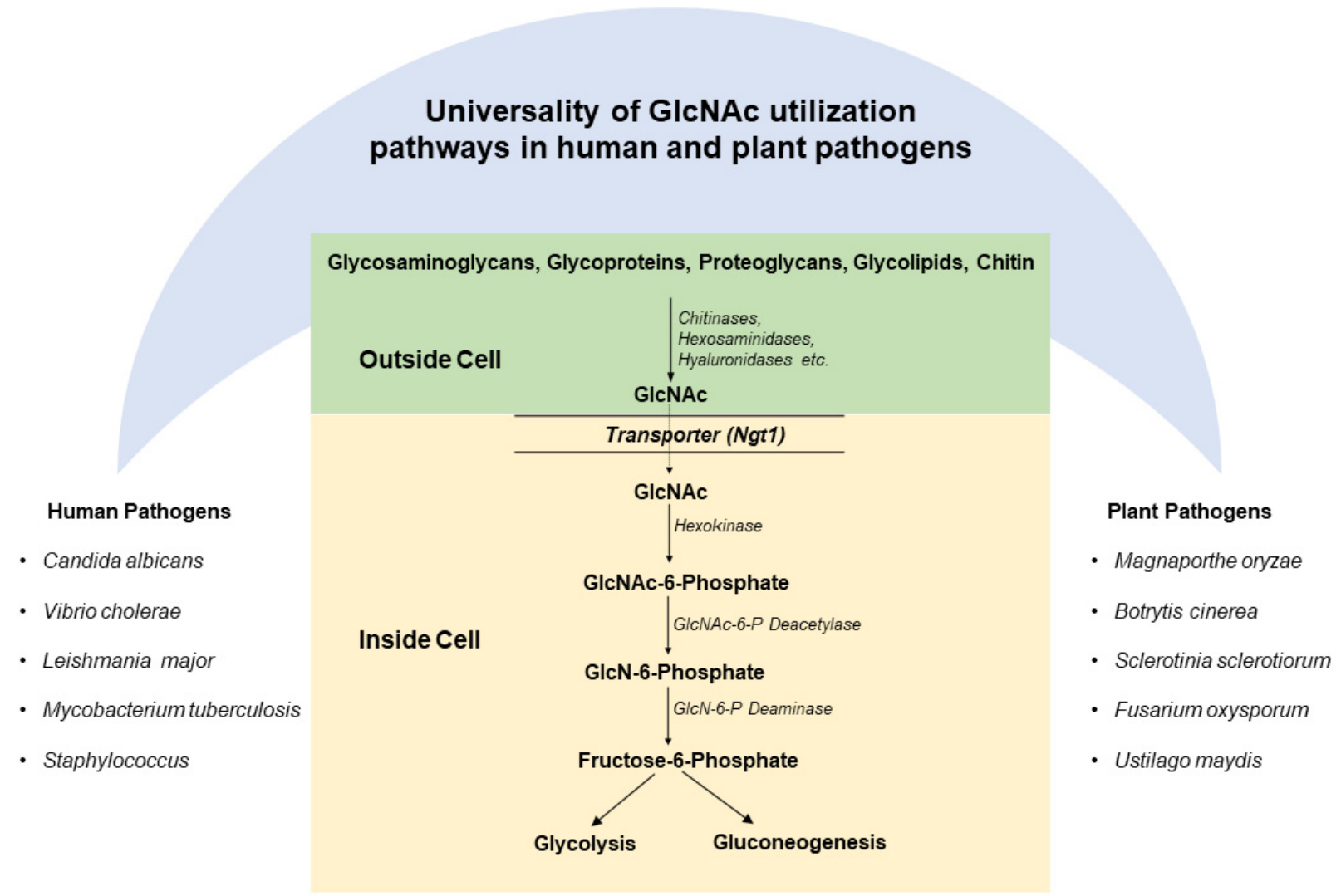

Figure 3. GlcNAc catabolic pathway: glycosaminoglycans, glycoproteins, proteoglycans, glycolipids, and chitin are the major sources of GlcNAc. Enzymes such as chitinases, hexosaminidases, hyaluronidases, etc., release free-GlcNAc from these macromolecules, which are taken up by the pathogens. The GlcNAc catabolic pathway involves three enzymes: hexokinase, GlcNAc-6-P deacetylase, and GlcNAc-6-P deaminase, which act sequentially to convert GlcNAc into fructose-6-phosphate.

\section{Engineering GlcNAc Catabolic Pathway for Reducing the Virulence of Human Pathogens}

Genetic engineering of human pathogens has contributed significantly to our understanding of human health and diseases. Since the emergence of knockout strategies, they have been the most commonly and widely used method for establishing an understanding of human pathogens. The emergence of more efficient knockout generation technologies, like CRISPR, has contributed considerably to the genetic engineering of pathogens [67]. C. albicans was among the first human pathogens in which the GlcNAc metabolic pathway was thoroughly studied, and Bhattacharya et al. [68] first reported that the presence of GlcNAc is essential for the induction of GlcNAc kinase. Further, several other GlcNAcregulated metabolic enzymes, such as permease, GlcNAc-6-P deacetylase, and GlcNAc-6-P deaminase in spheroplasts of $C$. albicans, were studied [69]. Moreover, Kumar et al. [70] reported that in C. albicans, GlcNAc catabolic genes (NAG1, DAC1, and HXK1) exist as a cluster and are under transcriptional activation in response to a single inducer GlcNAc [70]. Interestingly, this $N A G$ cluster contains $N A G 1$ and $D A C 1$ genes in opposite orientations, indicating the possibility of a bidirectional promoter [70]. The role of the GlcNAc catabolic pathway in virulence and pathogenesis was first established in C. albicans through the generation of several knockouts [28]. Disruption of the NAG operon of C. albicans by deletion of $D A C 1, N A G 1$, or HXK1, results in the generation of strain, which has attenuated virulence 
and pathogenesis [27,28]. Emerging data indicate that GlcNAc is utilized and sensed by a broad range of pathogens. The ubiquitous presence of GlcNAc and its role in inducing the virulence factors in many fungal and bacterial pathogens suggest the much-needed attention this pathway requires in several important human and plant pathogens.

After the establishment of the fact that the GlcNAc catabolic pathway is essential for the virulence and pathogenesis of $C$. albicans, this pathway was explored in other human pathogens. In Vibrio cholerae, two copies of DAC and GlcNAc kinase were identified, and an $\mathrm{N}$-acetylglucosamine-specific repressor $(\mathrm{NagC})$ performs dual functions by regulating classical GlcNAc catabolic pathway genes negatively and second copies of these genes positively. The null mutants of GlcNAc catabolic pathway genes showed attenuated virulence and pathogenesis during intestinal colonization. GlcNAc catabolic engineering approach was further exploited in a protozoan parasite Leishmania donovani. The $\Delta$ nagd mutant of Leishmania donovani showed impaired GlcNAc catabolism and was reported as indispensable for the viability of $L$. donovani in media containing GlcNAc as the sole carbon source [1]. Moreover, $\Delta$ nagd mutant exhibited attenuated virulence and reduced proliferation rate in THP-1 cells as compared to wild type [1]. Recently, null mutants of the GlcNAc catabolic pathway were also created in several other human pathogens such as S. mutans, Mycobacteria, Salmonella, etc., which also exhibited attenuated virulence and pathogenesis $[6,48,49,71]$.

\section{GlcNAc Metabolic Engineering for Reducing the Virulence of Plant Pathogens}

Similar to vertebrates and other animals, plants also interact with pathogens; however, plants do not have specialized immune cells. To combat this, plants have evolved intracellular immune receptors to recognize the presence of pathogen-associated molecular patterns (PAMPs) [72-74]. Bacterial and fungal cell-derived N-acetylglucosamine biopolymer is among the PAMP molecules that activate pattern-triggered immunity (PTI) in plants (Figure 4) [75]. Chitin, a polymer of GlcNAc and structural component of the fungal cell wall, triggers two major lysin motif receptor-like kinases, AtLYK5 and AtCERK1, in Arabidopsis [76]. AtLYK5 has a higher binding affinity to chitin than AtCERK1. Research studies show that chitin treatment activates the formation of tetramer complex, which further activates the chitin-triggered immunity in plants [77,78].

During the establishment of disease in plants, pathogen (microbe) and host (plant) interactions are tightly regulated at the molecular level. This pathological interaction not only hampers plant growth but also obstructs reproduction. It is important to know that to synthesize cell surface structures in bacteria, GlcNAc plays an important role. On entering the glycolytic pathway, GlcNAc could supply both carbon and energy as it can be converted into fructose-6-phosphate [50,51]. Kashulin et al. performed a study on tissue cultured potato cells with a fluorescent dye $2^{\prime}, 7^{\prime}$-dichlorofluorescein diacetate to understand the outcomes of polyunsaturated fatty acids together with GlcNAc and reported rapid generation of $\mathrm{H}_{2} \mathrm{O}_{2}$ in the cells [79]. This rapid (within 2-10 min) spur of free radicals may be associated with a plant safeguarding approach domineering a plantpathogen collaboration. To combat such pathogenic assault, many plants have developed defense proteins, which contain 'hevein domain' or 'chitin-binding' motif, and are skilled in reversible binding to polysaccharide chitin, a long-chain polymer of GlcNAc, present in the cell wall of fungi [80]. Asensio et al. employed various biochemical and spectroscopic approaches to understand the interactions of GlcNAc oligomers with hevein and ultimately established a structural foundation for detection of chitin by plant defense proteins [81].

Occurrence and/or omission of similar genes involved in plant resistance and pathogen avirulence governs plant-pathogen interactions. Kooman-Gersmann et al. applied AVR9 mutant peptides to establish the association among elicitor activity of AVR9 peptides and their affinity to bind tomato membranes [82]. Interestingly, they observed that Nglycosylation plays an important role, as AVR9 peptides with N-glycosylation exhibited a lesser affinity to the binding site than the non-glycosylated AVR9 peptides, while their necrosis stimulating endeavor was barely altered $[82,83]$. Additionally, tomato pathogen 
Cladosporium fulvum manifests AVR4 to protect fungi against plant chitinases [84-86]. Further, the importance of class $V$ chitin synthase in safeguarding vascular wilt pathogen Fusarium oxysporum against plant defense during host infection was also studied [87,88]. Jaroszuk-Ściseł et al. studied Fusarium isolates and their enzymatic complexes in the hydrolysis of the plant cell wall and/or fungal cell wall with distinctive assertiveness to Secale cereale and established that a plant growth-promoting rhizosphere isolate was effective in emancipating GlcNAc and reducing sugars from the cell wall of fungi $[89,90]$.

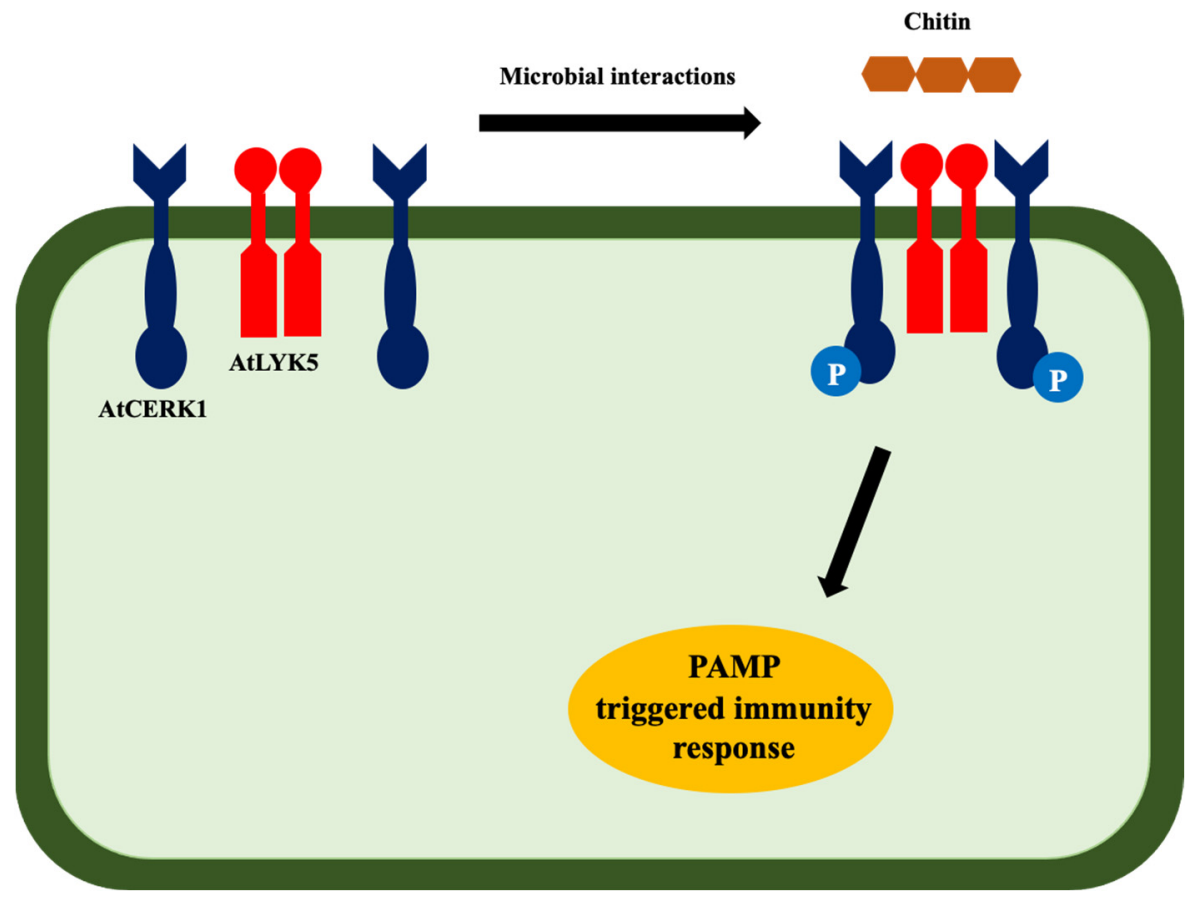

Figure 4. Chitin-triggered immunity in plants. Microbe-derived chitin activates the formation of tetramer [AtCERK1(AtLYK5)2 AtCERK1] that phosphorylates the AtCERK1 at the same time. This phosphorylation activates the PAMP-triggered immunity in plants [78].

Diverse soil microbes comprising symbionts and pathogens interact with plant roots, which advanced receptors to sense microbe-derived molecules. This mechanism helps plants to either allow the beneficial microbe to institute symbiosis or subsidize to decline a pathogen to prevent plant disease. Among the receptors, plant lysin motif proteins, which regulate the sensitivity of microbial-derived GlcNAc compounds, play a functional role in deciding symbiosis or preventing plant disease. Rey et al. studied LysM-receptor-like kinase mutants ( $n f p$ and $l y k 3$ ) of Medicago truncatula and examined them by subsequent inoculation with a root oomycete, Aphanomyces euteiches [91]. They found that $n f p$ (Nod Factor Perception) mutants show greater susceptibility to A. euteiches, while NFP overexpression enhances resistance to A. euteiches; however, they did not find any change in lyk3 (LysM domain receptor-like kinase 3) [91]. Further, the molecular basis for LysM modules in recognizing polysaccharides containing GlcNAc residues from AtlA, an autolysin of bacterial pathogen Enterococcus faecalis, was explored, and it was discovered that the LysM module distinguishes that the GlcNAc-X-GlcNAc motif exists in polysaccharides throughout all kingdoms [92]. Moreover, lysin motif receptors are also reported to be involved in the perception of GlcNAc-based saccharides released by pathogenic fungi [93]. Nars et al. reported the structural characterization and biological activity of atypical chitosaccharides from A. euteiches on the host Medicago truncatula and found that expression of defense marker genes is induced by glucan-chitosaccharide fractions of A. euteiches in Medicago [94]. Moreover, enhanced resistance from fungal pathogens by over-expressing chitinase genes have been successfully engineered in crop plants such as Solanum lycopersicum, Solanum tuberosum, Oryza sativa, Zea mays, groundnut, Brassica, finger millet, cotton, lychee, banana, 
Vitis vinifera, and wheat [95-98]. Furthermore, chitin-binding lectins (CBLs) are known for their role in immune defense against chitin encompassing pathogens by displaying antifungal properties as recombinant CBL in the $293 \mathrm{~F}$ cell culture supernatant could inhibit the growth of Rhizoctonia solani and Colletotrichum gloeosporioide [99]. Fungi are known for their capability to secrete extracellular degrader enzymes with hydrolytic functions. Barreto et al. suggest that GlcNAc has an important role in the secretion of extracellular chitinase in Metarhizium anisopliae [100,101].

During host-pathogen interactions, the successful establishment of pathogens is mostly dependent on accessibility and proficient consumption of host-derived nutrients by pathogens. To better understand this, Kumar et al. characterized the GlcNAc catabolic pathway genes such as GlcNAc transporter (MoNgt1), hexokinase, GlcNAc-6-phosphate deacetylase (MoDac), and GlcN-6-phosphate deaminase (MoDeam) during phytopathogen M. oryzae communication with host rice plant [65]. They proposed that GlcNAc supports fungus by the antioxidant defense to astounded oxidative stress inside its host, while in the impaired catabolic pathway, GlcNAc becomes toxic to the M. oryzae [65]. In line with this work, Bhatt et al. acknowledged a conserved transcriptional regulator, Ndt80/PhoG, in GlcNAc catabolic gene cluster in various fungi, including M. oryzae [64]. Interestingly, it was reported that MoNdt80 is indispensable for GlcNAc utilization and successful colonization and pathogenesis of $M$. oryzae in its host [64]. Other studies also support the role of GlcNAc metabolism (in planta and in vitro) in Xanthomonas campestris, a causal agent of black rot disease on Brassica [102-104]. To decode the molecular mechanism of Fusarium oxysporum and its host during infection, López-Fernández et al. discovered the presence of seven putative $\mathrm{N}$-glycosyl transferase encoding genes named gnt [105]. The $\Delta$ gnt2 mutant exhibited a decline in virulence on both plant and animal hosts, and the authors have concluded that $\mathrm{N}$-acetylglucosaminyl transferases are not only essential factors for cell wall structure but also stimulus interactions of $F$. oxysporum $[105,106]$.

Oligosaccharides with mixed linkages, $\beta-1,3 / 1,4$-glucan ( $\beta-1,3 / 1,4-\mathrm{MLG})$, are plentifully found in bacteria, oomycetes, symbionts, pathogenic or non-pathogenic fungi, and monocot plants. Barghahn et al. examined mutants of Arabidopsis innate-immunity signaling as well as more than 100 Arabidopsis ecotypes and hypothesized that $\beta-1,3 / 1,4-$ MLG oligosaccharides contain the two-fold capability to perform as immune active microbeassociated molecular patterns (MAMPs) and danger-associated molecular patterns (DAMPs) in both monocot and dicot plants [107]. Additionally, Rebaque et al. suggested that MLGs work as a cluster of carbohydrate-established molecular patterns and are noticed by plants to initiation their immune reactions and disease endurance $[108,109]$. Furthermore, three of the eight members of the LysM pattern recognition receptor (PRR) family, i.e., CERK1, LysM domain receptor-like kinase-4 (LYK4), and LysM domain receptor-like kinase-5 (LYK5) are involved in (GlcNAc)4-8 perception by Arabidopsis. Chitin Elicitor Receptor Kinase 1 (CERK1) identifies bacterial peptidoglycan MAMPs and chito-oligosaccharides from fungi to work as an immune co-receptor for linear 1,3- $\beta$-d-glucans [110].

\section{Conclusions and Future Prospects}

The emerging role of the GlcNAc catabolic pathway in different human and plant pathogens establishes the importance of this pathway in pathogenic diseases. Due to the continuous emergence of drug resistance among the parasites, there is a continuous search for newer drug targets. Therefore, studies on GlcNAc metabolic pathway in various human pathogens have provided the basis for new drug targets to manage microbial diseases. Recently characterized GlcNAc pathway in phytopathogen M. oryzae suggests the universality of this pathway in human and plant pathogens. Thus, it is clear that GlcNAc is universally required for the in vivo survival and virulence of diverse human and plant pathogens (Figure 1). With the technological advancement and genome editing approaches such as CRISPR-Cas9, in the future, additional novel roles of GlcNAc as a signaling molecule and GlcNAc engineering will continue to emerge in a diverse range of 
cell types. In the long term, enzymes and genes of the GlcNAc metabolic pathway could be used for the drug targets for controlling various human and plant diseases.

An assessment of the infectious host-pathogen interaction model has shown the virulence and defense mechanisms related to GlcNAc engineering. Although, there is still a scarcity in model pathosystems to examine GlcNAc function or GlcNAc perception by the host during pathological interactions. Hence, imminent improvement in this field will illustrate the critical role of GlcNAc signaling/perception during pathological interactions and also extend the co-adaptation of the pathogen, subsequently allowing pathogen invasion and host colonization. Indeed, such discernments will not only assist our understanding of advantageous versus disadvantageous communications but could also encourage resistance breeding in the future. Therefore, when new carbohydrate-based prospective DAMPs/MAMPs become accessible with the understanding of GlcNAc signaling/perception, we may be able to raise crop varieties harboring specific plant patternrecognition receptors and also design agricultural approaches that would augment crop disease resistance and modulate crop immunity.

Author Contributions: A.D. and M.I., conceived the idea; A.D. and M.I., designed the article; S.A., V.K., D.N.B. and M.I., mined the literature and wrote the draft manuscript; M.I. and A.D., reviewed and edited the manuscript. All authors have read and agreed to the published version of the manuscript.

Funding: Department of Biotechnology, Government of India.

Institutional Review Board Statement: Not applicable.

Informed Consent Statement: Not applicable.

Data Availability Statement: Not applicable.

Conflicts of Interest: The authors declare that they have no known competing financial interests or personal relationships that could influence the work reported in this paper.

$\begin{array}{ll}\text { Abbreviations } \\ \text { Avr9 } & \text { Avirulence gene } \\ \text { Camp } & \text { Cyclic adenosine monophosphate } \\ \text { CBLs } & \text { Chitin-binding lectins } \\ \text { CERK1 } & \text { Chitin elicitor receptor kinase 1 } \\ \text { CRISPR } & \text { Clustered regularly interspaced short palindromic repeats } \\ \text { DAC } & \text { N-acetyl glucosamine-6-phosphate deacetylase } \\ \text { DAMPs } & \text { Damage-associated molecular patterns } \\ \text { ECM } & \text { Extracellular Matrix } \\ \text { GI } & \text { Gastrointestinal } \\ \text { GlcNAc-1-P } & \text { N-acetylglucosamine-1-phosphate } \\ \text { GlcNAc-6-P } & \text { N-acetylglucosamine-6-phosphate } \\ \text { GlcNAc } & \text { N-acetylglucosamine } \\ \text { HXK } & \text { Hexokinase } \\ \text { LYK } & \text { LysM domain receptor-like kinase } \\ \text { lyk3 } & \text { LysM domain receptor-like kinase 3 } \\ \text { LysM } & \text { Lysin motif domain } \\ \text { MAMPs } & \text { Microbe-associated molecular patterns } \\ \text { NAG } & \text { glucosamine-6-phosphate deaminase } \\ \text { NFP } & \text { Nod factor perception } \\ \text { PRR } & \text { Pattern recognition receptor } \\ \text { PTS } & \text { Phosphotransferase system } \\ \text { PV } & \text { Parasitophorous vacuole } \\ \text { ROS } & \text { Reactive oxygen species } \\ \text { UDP-GlcNAc } & \text { Uridine diphosphate N-acetylglucosamine } \\ & \\ & \end{array}$




\section{References}

1. Ansari, S.; Bhatt, D.N.; Sood, C.; Datta, A. Functional Characterization of the LdNAGD Gene in Leishmania Donovani. Microbiol. Res. 2021, 251, 126830. [CrossRef] [PubMed]

2. Naderer, T.; Heng, J.; McConville, M.J. Evidence That Intracellular Stages of Leishmania Major Utilize Amino Sugars as a Major Carbon Source. PLoS Pathog. 2010, 6, e1001245. [CrossRef] [PubMed]

3. Horta, M.F.; Mendes, B.P.; Roma, E.H.; Noronha, F.S.M.; Macêdo, J.P.; Oliveira, L.S.; Duarte, M.M.; Vieira, L.Q. Reactive Oxygen Species and Nitric Oxide in Cutaneous Leishmaniasis. J. Parasitol. Res. 2012, 2012, 1-11. [CrossRef] [PubMed]

4. Ghosh, S.; Rao, K.H.; Sengupta, M.; Bhattacharya, S.K.; Datta, A. Two Gene Clusters Co-Ordinate for a Functional NAcetylglucosamine Catabolic Pathway in Vibrio Cholerae: New Insights into GlcNAc Catabolism of Vibrio Cholerae. Mol. Microbiol. 2011, 80, 1549-1560. [CrossRef]

5. Swiatek, M.A.; Tenconi, E.; Rigali, S.; van Wezel, G.P. Functional Analysis of the N-Acetylglucosamine Metabolic Genes of Streptomyces Coelicolor and Role in Control of Development and Antibiotic Production. J. Bacteriol. 2012, 194, 1136-1144. [CrossRef]

6. Miller, K.A.; Phillips, R.S.; Mrazek, J.; Hoover, T.R. Salmonella Utilizes D-Glucosaminate via a Mannose Family Phosphotransferase System Permease and Associated Enzymes. J. Bacteriol. 2013, 195, 4057-4066. [CrossRef]

7. Ruhela, D.; Kamthan, M.; Saha, P.; Majumdar, S.S.; Datta, K.; Abdin, M.Z.; Datta, A. In Vivo Role of Candida Albicans $\beta$ hexosaminidase (HEX 1) in Carbon Scavenging. MicrobiologyOpen 2015, 4, 730-742. [CrossRef]

8. Konopka, J.B. N-Acetylglucosamine Functions in Cell Signaling. Scientifica 2012, 2012, 1-15. [CrossRef]

9. Pennisi, E. Armed and Dangerous. Science 2010, 327, 804-805. [CrossRef]

10. Dean, R.; Van Kan, J.A.L.; Pretorius, Z.A.; Hammond-Kosack, K.E.; Di Pietro, A.; Spanu, P.D.; Rudd, J.J.; Dickman, M.; Kahmann, R.; Ellis, J.; et al. The Top 10 Fungal Pathogens in Molecular Plant Pathology: Top 10 Fungal Pathogens. Mol. Plant Pathol. 2012, 13, 414-430. [CrossRef] [PubMed]

11. Doehlemann, G.; Wahl, R.; Horst, R.J.; Voll, L.M.; Usadel, B.; Poree, F.; Stitt, M.; Pons-Kühnemann, J.; Sonnewald, U.; Kahmann, R.; et al. Reprogramming a Maize Plant: Transcriptional and Metabolic Changes Induced by the Fungal Biotroph. Ustilago Maydis: Plant Response to U. Maydis Infection. Plant J. 2008, 56, 181-195. [CrossRef] [PubMed]

12. Kumar, V.; Chattopadhyay, A.; Ghosh, S.; Irfan, M.; Chakraborty, N.; Chakraborty, S.; Datta, A. Improving Nutritional Quality and Fungal Tolerance in Soya Bean and Grass Pea by Expressing an Oxalate Decarboxylase. Plant Biotechnol. J. 2016, 14, $1394-1405$. [CrossRef] [PubMed]

13. Chandra, H.; Kumari, P.; Bisht, R.; Prasad, R.; Yadav, S. Plant Growth Promoting Pseudomonas Aeruginosa from Valeriana Wallichii Displays Antagonistic Potential against Three Phytopathogenic Fungi. Mol. Biol. Rep. 2020, 47, 6015-6026. [CrossRef]

14. Chandra, H.; Kumari, P.; Prasad, R.; Chandra Gupta, S.; Yadav, S. Antioxidant and Antimicrobial Activity Displayed by a Fungal Endophyte Alternaria Alternata Isolated from Picrorhiza Kurroa from Garhwal Himalayas, India. Biocatal. Agric. Biotechnol. 2021, 33, 101955. [CrossRef]

15. van Kan, J.A.L. Licensed to Kill: The Lifestyle of a Necrotrophic Plant Pathogen. Trends Plant Sci. 2006, 11, 247-253. [CrossRef]

16. Divon, H.H.; Fluhr, R. Nutrition Acquisition Strategies during Fungal Infection of Plants. FEMS Microbiol. Lett. 2007, 266, 65-74. [CrossRef] [PubMed]

17. Wilson, R.A.; Talbot, N.J. Under Pressure: Investigating the Biology of Plant Infection by Magnaporthe Oryzae. Nat. Rev. Microbiol 2009, 7, 185-195. [CrossRef]

18. Jaiswal, P.; Cheruku, J.R.; Kumar, K.; Yadav, S.; Singh, A.; Kumari, P.; Dube, S.C.; Upadhyaya, K.C.; Verma, P.K. Differential Transcript Accumulation in Chickpea during Early Phases of Compatible Interaction with a Necrotrophic Fungus Ascochyta Rabiei. Mol. Biol. Rep. 2012, 39, 4635-4646. [CrossRef]

19. Torres, M.A.; Jones, J.D.G.; Dangl, J.L. Reactive Oxygen Species Signaling in Response to Pathogens. Plant Physiol. 2006, 141, 373-378. [CrossRef]

20. Yadav, S.; Kushwaha, H.R.; Kumar, K.; Verma, P.K. Comparative Structural Modeling of a Monothiol GRX from Chickpea: Insight in Iron-Sulfur Cluster Assembly. Int. J. Biol. Macromol. 2012, 51, 266-273. [CrossRef]

21. Kliebenstein, D.J.; Rowe, H.C. Ecological Costs of Biotrophic versus Necrotrophic Pathogen Resistance, the Hypersensitive Response and Signal Transduction. Plant Sci. 2008, 174, 551-556. [CrossRef]

22. Glazebrook, J. Contrasting Mechanisms of Defense Against Biotrophic and Necrotrophic Pathogens. Annu. Rev. Phytopathol. 2005, 43, 205-227. [CrossRef] [PubMed]

23. Kumari, P.; Gupta, A.; Yadav, S. Thioredoxins as Molecular Players in Plants, Pests, and Pathogens. In Plant-Pest Interactions: From Molecular Mechanisms to Chemical Ecology; Singh, I.K., Singh, A., Eds.; Springer: Singapore, 2021; pp. 107-125. [CrossRef]

24. Naseem, S.; Konopka, J.B. N-Acetylglucosamine Regulates Virulence Properties in Microbial Pathogens. PLoS Pathog. 2015, 11, e1004947. [CrossRef] [PubMed]

25. Moussian, B. The Role of GlcNAc in Formation and Function of Extracellular Matrices. Comp. Biochem. Physiol. Part B Biochem. Mol. Biol. 2008, 149, 215-226. [CrossRef] [PubMed]

26. Du, H.; Guan, G.; Li, X.; Gulati, M.; Tao, L.; Cao, C.; Johnson, A.D.; Nobile, C.J.; Huang, G. N-Acetylglucosamine-Induced Cell Death in Candida Albicans and Its Implications for Adaptive Mechanisms of Nutrient Sensing in Yeasts. mBio 2015, 6, e01376-15. [CrossRef] [PubMed] 
27. Datta, A.; Ganesan, K.; Natarajan, K. Current Trends in Candida Albicans Research. In Advances in Microbial Physiology; Elsevier: Amsterdam, The Netherlands, 1990; Volume 30, pp. 53-88. [CrossRef]

28. Singh, P.; Ghosh, S.; Datta, A. Attenuation of Virulence and Changes in Morphology in Candida Albicans by Disruption of the N-Acetylglucosamine Catabolic Pathway. Infect. Immun. 2001, 69, 7898-7903. [CrossRef]

29. Olszewski, N.E.; West, C.M.; Sassi, S.O.; Hartweck, L.M. O-GlcNAc Protein Modification in Plants: Evolution and Function. Biochim. Et Biophys. Acta (BBA) Gen. Subj. 2010, 1800, 49-56. [CrossRef]

30. Meli, V.S.; Ghosh, S.; Prabha, T.N.; Chakraborty, N.; Chakraborty, S.; Datta, A. Enhancement of Fruit Shelf Life by Suppressing N-Glycan Processing Enzymes. Proc. Natl. Acad. Sci. USA 2010, 107, 2413-2418. [CrossRef]

31. Ghosh, S.; Meli, V.S.; Kumar, A.; Thakur, A.; Chakraborty, N.; Chakraborty, S.; Datta, A. The N-Glycan Processing Enzymes $\alpha$-Mannosidase and $\beta$-D-N-Acetylhexosaminidase Are Involved in Ripening-Associated Softening in the Non-Climacteric Fruits of Capsicum. J. Exp. Bot. 2011, 62, 571-582. [CrossRef]

32. Irfan, M.; Ghosh, S.; Meli, V.S.; Kumar, A.; Kumar, V.; Chakraborty, N.; Chakraborty, S.; Datta, A. Fruit Ripening Regulation of $\alpha$-Mannosidase Expression by the MADS Box Transcription Factor RIPENING INHIBITOR and Ethylene. Front. Plant Sci. 2016, 7, 10. [CrossRef]

33. Irfan, M.; Ghosh, S.; Kumar, V.; Chakraborty, N.; Chakraborty, S.; Datta, A. Insights into Transcriptional Regulation of -D-NAcetylhexosaminidase, an N-Glycan-Processing Enzyme Involved in Ripening-Associated Fruit Softening. J. Exp. Bot. 2014, 65, 5835-5848. [CrossRef] [PubMed]

34. Sumit Ghosh, S.G.; Mohammad Irfan, M.I.; Asis Datta, A.D. Application of RNA Silencing in Improving Plant Traits for Industrial Use. In Plant Gene Silencing: Mechanisms and Applications; Dalmay, T., Ed.; CABI: Wallingford, UK, 2017; pp. 128-146. [CrossRef]

35. Ishikawa, T.; Fang, L.; Rennie, E.A.; Sechet, J.; Yan, J.; Jing, B.; Moore, W.; Cahoon, E.B.; Scheller, H.V.; Kawai-Yamada, M.; et al GLUCOSAMINE INOSITOLPHOSPHORYLCERAMIDE TRANSFERASE1 (GINT1) Is a GlcNAc-Containing Glycosylinositol Phosphorylceramide Glycosyltransferase. Plant Physiol. 2018, 177, 938-952. [CrossRef]

36. Skoog, E.C.; Sjöling, Å.; Navabi, N.; Holgersson, J.; Lundin, S.B.; Lindén, S.K. Human Gastric Mucins Differently Regulate Helicobacter Pylori Proliferation, Gene Expression and Interactions with Host Cells. PLoS ONE 2012, 7, e36378. [CrossRef] [PubMed]

37. Reddi, G.; Pruss, K.; Cottingham, K.L.; Taylor, R.K.; Almagro-Moreno, S. Catabolism of Mucus Components Influences Motility of Vibrio Cholerae in the Presence of Environmental Reservoirs. PLoS ONE 2018, 13, e0201383. [CrossRef] [PubMed]

38. Li, X.; Bleumink-Pluym, N.M.C.; Luijkx, Y.M.C.A.; Wubbolts, R.W.; van Putten, J.P.M.; Strijbis, K. MUC1 Is a Receptor for the Salmonella SiiE Adhesin That Enables Apical Invasion into Enterocytes. PLoS Pathog. 2019, 15, e1007566. [CrossRef] [PubMed]

39. Cavalcante, T.; Medeiros, M.M.; Mule, S.N.; Palmisano, G.; Stolf, B.S. The Role of Sialic Acids in the Establishment of Infections by Pathogens, With Special Focus on Leishmania. Front. Cell. Infect. Microbiol. 2021, 11, 671913. [CrossRef]

40. Kato, K.; Ishiwa, A. The Role of Carbohydrates in Infection Strategies of Enteric Pathogens. Trop. Med. Health 2015, 43, 41-52. [CrossRef]

41. Azzouz, N.; Shams-Eldin, H.; Niehus, S.; Debierre-Grockiego, F.; Bieker, U.; Schmidt, J.; Mercier, C.; Delauw, M.-F.; Dubremetz, J.-F.; Smith, T.K.; et al. Toxoplasma Gondii Grown in Human Cells Uses GalNAc-Containing Glycosylphosphatidylinositol Precursors to Anchor Surface Antigens While the Immunogenic Glc-GalNAc-Containing Precursors Remain Free at the Parasite Cell Surface. Int. J. Biochem. Cell Biol. 2006, 38, 1914-1925. [CrossRef]

42. Sheikh, A.; Wangdi, T.; Vickers, T.J.; Aaron, B.; Palmer, M.; Miller, M.J.; Kim, S.; Herring, C.; Simoes, R.; Crainic, J.A.; et al. Enterotoxigenic Escherichia Coli Degrades the Host MUC2 Mucin Barrier to Facilitate Critical Pathogen-Enterocyte Interactions in Human Small Intestine. Infect. Immun. 2021, IAI-00572. [CrossRef]

43. Van Ende, M.; Wijnants, S.; Van Dijck, P. Sugar Sensing and Signaling in Candida Albicans and Candida Glabrata. Front. Microbiol. 2019, 10, 99. [CrossRef]

44. Puri, S.; Friedman, J.; Saraswat, D.; Kumar, R.; Li, R.; Ruszaj, D.; Edgerton, M. Candida Albicans Shed Msb2 and Host Mucins Affect the Candidacidal Activity of Salivary Hst 5. Pathogens 2015, 4, 752-763. [CrossRef] [PubMed]

45. Everard, A.; Belzer, C.; Geurts, L.; Ouwerkerk, J.P.; Druart, C.; Bindels, L.B.; Guiot, Y.; Derrien, M.; Muccioli, G.G.; Delzenne, N.M.; et al. Cross-Talk between Akkermansia Muciniphila and Intestinal Epithelium Controls Diet-Induced Obesity. Proc. Natl. Acad. Sci. USA 2013, 110, 9066-9071. [CrossRef] [PubMed]

46. Geerlings, S.; Kostopoulos, I.; de Vos, W.; Belzer, C. Akkermansia Muciniphila in the Human Gastrointestinal Tract: When, Where, and How? Microorganisms 2018, 6, 75. [CrossRef] [PubMed]

47. Pereira, F.C.; Wasmund, K.; Cobankovic, I.; Jehmlich, N.; Herbold, C.W.; Lee, K.S.; Sziranyi, B.; Vesely, C.; Decker, T.; Stocker, R.; et al. Rational Design of a Microbial Consortium of Mucosal Sugar Utilizers Reduces Clostridiodes Difficile Colonization. Nat. Commun. 2020, 11, 5104. [CrossRef] [PubMed]

48. Shuter, J.; Hatcher, V.B.; Lowy, F.D. Staphylococcus Aureus Binding to Human Nasal Mucin. Infect. Immun. 1996, 64, 310-318. [CrossRef]

49. Olson, M.E.; King, J.M.; Yahr, T.L.; Horswill, A.R. Sialic Acid Catabolism in Staphylococcus Aureus. J. Bacteriol. 2013, 195, 1779-1788. [CrossRef]

50. Kloehn, J.; Blume, M.; Cobbold, S.; Saunders, E.; Dagley, M.; McConville, M. Using Metabolomics to Dissect Host-Parasite Interactions. Curr. Opin. Microbiol. 2016, 32, 59-65. [CrossRef] 
51. Ghosh, A.K.; Sardar, A.H.; Mandal, A.; Saini, S.; Abhishek, K.; Kumar, A.; Purkait, B.; Singh, R.; Das, S.; Mukhopadhyay, R.; et al. Metabolic Reconfiguration of the Central Glucose Metabolism: A Crucial Strategy of Leishmania Donovani for Its Survival during Oxidative Stress. FASEB J. 2015, 29, 2081-2098. [CrossRef]

52. Kamthan, A.; Kamthan, M.; Datta, A. Biotechnology for Drug Discovery and Crop Improvement. Nucleus 2017, 60, 237-242. [CrossRef]

53. Biswas, S.; Van Dijck, P.; Datta, A. Environmental Sensing and Signal Transduction Pathways Regulating Morphopathogenic Determinants of Candida Albicans. Microbiol. Mol. Biol. Rev. 2007, 71, 348-376. [CrossRef]

54. Ghorai, P.; Irfan, M.; Narula, A.; Datta, A. A Comprehensive Analysis of Candida Albicans Phosphoproteome Reveals Dynamic Changes in Phosphoprotein Abundance during Hyphal Morphogenesis. Appl. Microbiol. Biotechnol. 2018, 102, 9731-9743. [CrossRef] [PubMed]

55. Kamthan, M.; Mukhopadhyay, G.; Chakraborty, N.; Chakraborty, S.; Datta, A. Quantitative Proteomics and Metabolomics Approaches to Demonstrate N-Acetyl-d-Glucosamine Inducible Amino Acid Deprivation Response as Morphological Switch in Candida Albicans. Fungal Genet. Biol. 2012, 49, 369-378. [CrossRef] [PubMed]

56. Hanumantha Rao, K.; Paul, S.; Ghosh, S. N-Acetylglucosamine Signaling: Transcriptional Dynamics of a Novel Sugar Sensing Cascade in a Model Pathogenic Yeast, Candida Albicans. JoF 2021, 7, 65. [CrossRef] [PubMed]

57. Vesely, E.M.; Williams, R.B.; Konopka, J.B.; Lorenz, M.C. N-Acetylglucosamine Metabolism Promotes Survival of Candida Albicans in the Phagosome. mSphere 2017, 2, e00357-17. [CrossRef] [PubMed]

58. Kamthan, M.; Kamthan, A.; Ruhela, D.; Maiti, P.; Bhavesh, N.S.; Datta, A. Upregulation of Galactose Metabolic Pathway by N-Acetylglucosamine Induced Endogenous Synthesis of Galactose in Candida Albicans. Fungal Genet. Biol. 2013, 54, 15-24. [CrossRef] [PubMed]

59. Shen, A.; Kamp, H.D.; Gründling, A.; Higgins, D.E. A Bifunctional O-GlcNAc Transferase Governs Flagellar Motility through Anti-Repression. Genes Dev. 2006, 20, 3283-3295. [CrossRef] [PubMed]

60. Grigorian, A.; Araujo, L.; Naidu, N.N.; Place, D.J.; Choudhury, B.; Demetriou, M. N-Acetylglucosamine Inhibits T-Helper 1 (Th1)/T-Helper 17 (Th17) Cell Responses and Treats Experimental Autoimmune Encephalomyelitis. J. Biol. Chem. 2011, 286, 40133-40141. [CrossRef] [PubMed]

61. Stokes, M.J.; Güther, M.L.S.; Turnock, D.C.; Prescott, A.R.; Martin, K.L.; Alphey, M.S.; Ferguson, M.A.J. The Synthesis of UDP-NAcetylglucosamine Is Essential for Bloodstream Form Trypanosoma Brucei in Vitro and in Vivo and UDP-N-Acetylglucosamine Starvation Reveals a Hierarchy in Parasite Protein Glycosylation. J. Biol. Chem. 2008, 283, 16147-16161. [CrossRef]

62. Soni, V.; Upadhayay, S.; Suryadevara, P.; Samla, G.; Singh, A.; Yogeeswari, P.; Sriram, D.; Nandicoori, V.K. Depletion of M. Tuberculosis GlmU from Infected Murine Lungs Effects the Clearance of the Pathogen. PLoS Pathog. 2015, 11, e1005235. [CrossRef]

63. Zhou, Y.; Xin, Y.; Sha, S.; Ma, Y. Kinetic Properties of Mycobacterium Tuberculosis Bifunctional GlmU. Arch Microbiol. 2011, 193, 751-757. [CrossRef]

64. Bhatt, D.N.; Ansari, S.; Kumar, A.; Ghosh, S.; Narula, A.; Datta, A. Magnaporthe Oryzae MoNdt80 Is a Transcriptional Regulator of GlcNAc Catabolic Pathway Involved in Pathogenesis. Microbiol. Res. 2020, 239, 126550. [CrossRef] [PubMed]

65. Kumar, A.; Ghosh, S.; Bhatt, D.N.; Narula, A.; Datta, A. M Agnaporthe Oryzae Aminosugar Metabolism Is Essential for Successful Host Colonization: N-Acetylglucosamine Metabolism by Rice Blast Fungus. Environ. Microbiol. 2016, 18, 1063-1077. [CrossRef] [PubMed]

66. Ferreira, F.M.; Mendoza-Hernandez, G.; Castañeda-Bueno, M.; Aparicio, R.; Fischer, H.; Calcagno, M.L.; Oliva, G. Structural Analysis of N-Acetylglucosamine-6-Phosphate Deacetylase Apoenzyme from Escherichia Coli. J. Mol. Biol. 2006, 359, 308-321. [CrossRef] [PubMed]

67. Ishibashi, A.; Saga, K.; Hisatomi, Y.; Li, Y.; Kaneda, Y.; Nimura, K. A Simple Method Using CRISPR-Cas9 to Knock-out Genes in Murine Cancerous Cell Lines. Sci. Rep. 2020, 10, 22345. [CrossRef] [PubMed]

68. Bhattacharya, A.; Puri, M.; Datta, A. Induction of N-Acetylglucosamine Kinase in Yeast. Biochem. J. 1974, 141, 593-595. [CrossRef] [PubMed]

69. Singh, B.; Datta, A. Induction of N-Acetylglucosamine-Catabolic Pathway in Spheroplasts of Candida Albicans. Biochem. J. 1979, 178, 427-431. [CrossRef]

70. Kumar, M.J.; Jamaluddin, Md. S.; Natarajan, K.; Kaur, D.; Datta, A. The Inducible N-Acetylglucosamine Catabolic Pathway Gene Cluster in Candida Albicans: Discrete N-Acetylglucosamine-Inducible Factors Interact at the Promoter of NAG1. Proc. Natl. Acad. Sci. USA 2000, 97, 14218-14223. [CrossRef]

71. Moye, Z.D.; Burne, R.A.; Zeng, L. Uptake and Metabolism of N-Acetylglucosamine and Glucosamine by Streptococcus Mutans. Appl. Environ. Microbiol. 2014, 80, 5053-5067. [CrossRef]

72. Spoel, S.H.; Dong, X. How Do Plants Achieve Immunity? Defence without Specialized Immune Cells. Nat. Rev. Immunol. 2012, 12, 89-100. [CrossRef]

73. Choi, H.W.; Klessig, D.F. DAMPs, MAMPs, and NAMPs in Plant Innate Immunity. BMC Plant Biol. 2016, 16, 232. [CrossRef]

74. Zhang, J.; Zhou, J.-M. Plant Immunity Triggered by Microbial Molecular Signatures. Mol. Plant 2010, 3, 783-793. [CrossRef] [PubMed]

75. Wan, J.; Zhang, X.-C.; Stacey, G. Chitin Signaling and Plant Disease Resistance. Plant Signal. Behav. 2008, 3, 831-833. [CrossRef] [PubMed] 
76. Desaki, Y.; Miyata, K.; Suzuki, M.; Shibuya, N.; Kaku, H. Plant Immunity and Symbiosis Signaling Mediated by LysM Receptors. Innate Immun. 2018, 24, 92-100. [CrossRef] [PubMed]

77. Huang, C.; Yan, Y.; Zhao, H.; Ye, Y.; Cao, Y. Arabidopsis CPK5 Phosphorylates the Chitin Receptor LYK5 to Regulate Plant Innate Immunity. Front. Plant Sci. 2020, 11, 702. [CrossRef] [PubMed]

78. Cao, Y.; Liang, Y.; Tanaka, K.; Nguyen, C.T.; Jedrzejczak, R.P.; Joachimiak, A.; Stacey, G. The Kinase LYK5 Is a Major Chitin Receptor in Arabidopsis and Forms a Chitin-Induced Complex with Related Kinase CERK1. eLife 2014, 3, e03766. [CrossRef] [PubMed]

79. Kashulin, P.A.; Merzlyak, M.N.; Zhiboedov, P.M.; Zhirov, V.K. Extremely Rapid Effects of Polyunsaturated Fatty Acids and N-Acetylglucosamine on Free-Radical Metabolism in Cultured Potato Plant Cells. Biochem. Soc. Trans. 2000, $28,865-867$. [CrossRef]

80. Raikhel, N.V.; Lee, H.I.; Broekaert, W.F. Structure and Function of Chitin-Binding Proteins. Annu. Rev. Plant Physiol. Plant Mol. Biol. 1993, 44, 591-615. [CrossRef]

81. Asensio, J.L.; Cañada, F.J.; Siebert, H.C.; Laynez, J.; Poveda, A.; Nieto, P.M.; Soedjanaamadja, U.M.; Gabius, H.J.; Jiménez-Barbero, J. Structural Basis for Chitin Recognition by Defense Proteins: GlcNAc Residues Are Bound in a Multivalent Fashion by Extended Binding Sites in Hevein Domains. Chem. Biol. 2000, 7, 529-543. [CrossRef]

82. Kooman-Gersmann, M.; Vogelsang, R.; Vossen, P.; van den Hooven, H.W.; Mahé, E.; Honée, G.; de Wit, P.J. Correlation between Binding Affinity and Necrosis-Inducing Activity of Mutant AVR9 Peptide Elicitors. Plant Physiol. 1998, 117, 609-618. [CrossRef]

83. Kourelis, J.; van der Hoorn, R.A.L. Defended to the Nines: 25 Years of Resistance Gene Cloning Identifies Nine Mechanisms for R Protein Function. Plant Cell 2018, 30, 285-299. [CrossRef]

84. van den Burg, H.A.; Spronk, C.A.E.M.; Boeren, S.; Kennedy, M.A.; Vissers, J.P.C.; Vuister, G.W.; de Wit, P.J.G.M.; Vervoort, J. Binding of the AVR4 Elicitor of Cladosporium Fulvum to Chitotriose Units Is Facilitated by Positive Allosteric Protein-Protein Interactions: The Chitin-Binding Site of AVR4 Represents a Novel Binding Site on the Folding Scaffold Shared between the Invertebrate and the Plant Chitin-Binding Domain. J. Biol. Chem. 2004, 279, 16786-16796. [CrossRef] [PubMed]

85. van den Burg, H.A.; Harrison, S.J.; Joosten, M.H.A.J.; Vervoort, J.; de Wit, P.J.G.M. Cladosporium Fulvum Avr4 Protects Fungal Cell Walls against Hydrolysis by Plant Chitinases Accumulating during Infection. Mol. Plant Microbe Interact. 2006, 19, 1420-1430. [CrossRef] [PubMed]

86. van Esse, H.P.; Bolton, M.D.; Stergiopoulos, I.; de Wit, P.J.G.M.; Thomma, B.P.H.J. The Chitin-Binding Cladosporium Fulvum Effector Protein Avr4 Is a Virulence Factor. Mol. Plant Microbe Interact. 2007, 20, 1092-1101. [CrossRef] [PubMed]

87. Martín-Urdíroz, M.; Roncero, M.I.G.; González-Reyes, J.A.; Ruiz-Roldán, C. ChsVb, a Class VII Chitin Synthase Involved in Septation, Is Critical for Pathogenicity in Fusarium Oxysporum. Eukaryot. Cell 2008, 7, 112-121. [CrossRef]

88. Madrid, M.P.; Di Pietro, A.; Roncero, M.I.G. Class V Chitin Synthase Determines Pathogenesis in the Vascular Wilt Fungus Fusarium Oxysporum and Mediates Resistance to Plant Defence Compounds. Mol. Microbiol. 2003, 47, 257-266. [CrossRef]

89. Jaroszuk-Ściset, J.; Kurek, E. Hydrolysis of Fungal and Plant Cell Walls by Enzymatic Complexes from Cultures of Fusarium Isolates with Different Aggressiveness to Rye (Secale Cereale). Arch Microbiol. 2012, 194, 653-665. [CrossRef]

90. Jaroszuk-Scisel, J.; Kurek, E.; Slomka, A.; Janczarek, M.; Rodzik, B. Activities of Cell Wall Degrading Enzymes in Autolyzing Cultures of Three Fusarium Culmorum Isolates: Growth-Promoting, Deleterious and Pathogenic to Rye (Secale Cereale). Mycologia 2011, 103, 929-945. [CrossRef]

91. Rey, T.; Nars, A.; Bonhomme, M.; Bottin, A.; Huguet, S.; Balzergue, S.; Jardinaud, M.-F.; Bono, J.-J.; Cullimore, J.; Dumas, B.; et al. NFP, a LysM Protein Controlling Nod Factor Perception, Also Intervenes in Medicago Truncatula Resistance to Pathogens. New Phytol. 2013, 198, 875-886. [CrossRef]

92. Mesnage, S.; Dellarole, M.; Baxter, N.J.; Rouget, J.-B.; Dimitrov, J.D.; Wang, N.; Fujimoto, Y.; Hounslow, A.M.; Lacroix-Desmazes, S.; Fukase, K.; et al. Molecular Basis for Bacterial Peptidoglycan Recognition by LysM Domains. Nat. Commun. 2014, 5, 4269. [CrossRef]

93. Nars, A.; Rey, T.; Lafitte, C.; Vergnes, S.; Amatya, S.; Jacquet, C.; Dumas, B.; Thibaudeau, C.; Heux, L.; Bottin, A.; et al. An Experimental System to Study Responses of Medicago Truncatula Roots to Chitin Oligomers of High Degree of Polymerization and Other Microbial Elicitors. Plant Cell Rep. 2013, 32, 489-502. [CrossRef]

94. Nars, A.; Lafitte, C.; Chabaud, M.; Drouillard, S.; Mélida, H.; Danoun, S.; Le Costaouëc, T.; Rey, T.; Benedetti, J.; Bulone, V.; et al. Aphanomyces Euteiches Cell Wall Fractions Containing Novel Glucan-Chitosaccharides Induce Defense Genes and Nuclear Calcium Oscillations in the Plant Host Medicago Truncatula. PLoS ONE 2013, 8, e75039. [CrossRef]

95. Cletus, J.; Balasubramanian, V.; Vashisht, D.; Sakthivel, N. Transgenic Expression of Plant Chitinases to Enhance Disease Resistance. Biotechnol. Lett. 2013, 35, 1719-1732. [CrossRef] [PubMed]

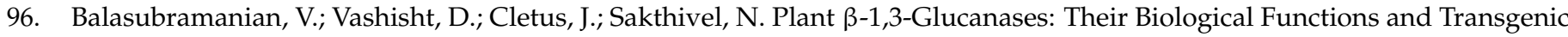
Expression against Phytopathogenic Fungi. Biotechnol. Lett. 2012, 34, 1983-1990. [CrossRef] [PubMed]

97. Punja, Z.K.; Zhang, Y.Y. Plant Chitinases and Their Roles in Resistance to Fungal Diseases. J. Nematol. 1993, 25, 526-540.

98. Langner, T.; Göhre, V. Fungal Chitinases: Function, Regulation, and Potential Roles in Plant/Pathogen Interactions. Curr. Genet. 2016, 62, 243-254. [CrossRef]

99. Chen, C.-S.; Chen, C.-Y.; Ravinath, D.M.; Bungahot, A.; Cheng, C.-P.; You, R.-I. Functional Characterization of Chitin-Binding Lectin from Solanum Integrifolium Containing Anti-Fungal and Insecticidal Activities. BMC Plant Biol. 2018, 18, 3. [CrossRef] 
100. Krieger de Moraes, C.; Schrank, A.; Vainstein, M.H. Regulation of Extracellular Chitinases and Proteases in the Entomopathogen and Acaricide Metarhizium Anisopliae. Curr. Microbiol. 2003, 46, 205-210. [CrossRef]

101. Barreto, C.C.; Staats, C.C.; Schrank, A.; Vainstein, M.H. Distribution of Chitinases in the Entomopathogen Metarhizium Anisopliae and Effect of N-Acetylglucosamine in Protein Secretion. Curr. Microbiol. 2004, 48, 102-107. [CrossRef]

102. Dupoiron, S.; Zischek, C.; Ligat, L.; Carbonne, J.; Boulanger, A.; Dugé de Bernonville, T.; Lautier, M.; Rival, P.; Arlat, M.; Jamet, E.; et al. The N-Glycan Cluster from Xanthomonas Campestris Pv. Campestris: A Toolbox for Sequential Plant N-Glycan Processing. J. Biol. Chem. 2015, 290, 6022-6036. [CrossRef]

103. Boulanger, A.; Zischek, C.; Lautier, M.; Jamet, S.; Rival, P.; Carrère, S.; Arlat, M.; Lauber, E. The Plant Pathogen Xanthomonas Campestris Pv. Campestris Exploits N-Acetylglucosamine during Infection. mBio 2014, 5, e01527-14. [CrossRef]

104. Boulanger, A.; Déjean, G.; Lautier, M.; Glories, M.; Zischek, C.; Arlat, M.; Lauber, E. Identification and Regulation of the NAcetylglucosamine Utilization Pathway of the Plant Pathogenic Bacterium Xanthomonas Campestris Pv. Campestris. J. Bacteriol. 2010, 192, 1487-1497. [CrossRef] [PubMed]

105. López-Fernández, L.; Ruiz-Roldán, C.; Pareja-Jaime, Y.; Prieto, A.; Khraiwesh, H.; Roncero, M.I.G. The Fusarium Oxysporum Gnt2, Encoding a Putative N-Acetylglucosamine Transferase, Is Involved in Cell Wall Architecture and Virulence. PLoS ONE 2013, 8, e84690. [CrossRef] [PubMed]

106. Lopez-Fernandez, L.; Roncero, M.I.G.; Prieto, A.; Ruiz-Roldan, C. Comparative Proteomic Analyses Reveal That Gnt2-Mediated N-Glycosylation Affects Cell Wall Glycans and Protein Content in Fusarium Oxysporum. J. Proteom. 2015, 128, 189-202. [CrossRef] [PubMed]

107. Barghahn, S.; Arnal, G.; Jain, N.; Petutschnig, E.; Brumer, H.; Lipka, V. Mixed Linkage $\beta-1,3 / 1,4-G l u c a n$ Oligosaccharides Induce Defense Responses in Hordeum Vulgare and Arabidopsis Thaliana. Front. Plant Sci. 2021, 12, 682439. [CrossRef]

108. Del Hierro, I.; Mélida, H.; Broyart, C.; Santiago, J.; Molina, A. Computational Prediction Method to Decipher Receptor-Glycoligand Interactions in Plant Immunity. Plant J. 2021, 105, 1710-1726. [CrossRef]

109. Rebaque, D.; Del Hierro, I.; López, G.; Bacete, L.; Vilaplana, F.; Dallabernardina, P.; Pfrengle, F.; Jordá, L.; Sánchez-Vallet, A.; Pérez, R.; et al. Cell Wall-Derived Mixed-Linked $\beta-1,3 / 1,4-G l u c a n s$ Trigger Immune Responses and Disease Resistance in Plants. Plant J. 2021, 106, 601-615. [CrossRef]

110. Mélida, H.; Sopeña-Torres, S.; Bacete, L.; Garrido-Arandia, M.; Jordá, L.; López, G.; Muñoz-Barrios, A.; Pacios, L.F.; Molina, A. Non-Branched $\beta-1,3-G l u c a n$ Oligosaccharides Trigger Immune Responses in Arabidopsis. Plant J. 2018, 93, 34-49. [CrossRef] 